DOI: 10.34015/2523-4552.2019.3.06

УДК 340.155.2:343.26

Сокальська О. В., кандидат юридичних наук, доцент e-mail:co2001@ukr.net

ORCID ID: 0000-0001-8737-0829

\title{
«ПРАГНЕННЯ РЕФОРМ»: ТЮРЕМНІ ПЕРЕТВОРЕННЯ У ВЕЛИКІЙ БРИТАНІЇ У 70-Х РОКАХ XVIII СТОЛІТТЯ
}

У статті проаналізовано суспільно-політичні умови, що призвели до перегляду англійської системи покарань, визначено причини та етапи тюремних перетворень у Великій Британії у 70-х роках XVIII ст., окреслено ідеї та погляди філософів, філантропів та правників (Семюеля Денна, Вільяма Сміта, Джонаса Хенуея, Вільяма Ідена, Вільяма Блекстона та ін.) щодо модернізації тюрем, їх внесок у формування концепту виправного покарання. Особлива увага приділена процесу розробки та основним положенням тюремних актів 1774 р., Акта про халки 1776 р., законопроєкту про каторжну працю 1778 р. та Пенітенціарного акта $1779 \mathrm{p}$.

Ключові слова: Велика Британія; соціальні реформи; в'язниці; транспортація; одиночне ув'язнення; каторжна праця; Пенітенціарний акт 1779 р.

В статье проанализированы общественно-политические условия, в которых происходил пересмотр английской системы наказаний, причины и этапы тюремных преобразований в Великобритании в 70-х годах XVIII в., определены идеи и взгляды философов, филантропов и юристов (Сэмюеля Денна, Уильяма Смита, Джонаса Хенвэя, Уильяма Идена, Уильяма Блэкстона и др.) на модернизацию тюрем, их влияние на формирование концепта исправительного наказания. Особое внимание уделено процессу разработки и содержанию тюремных актов 1774 г., Акта о халках 1776 г., законопроекта о каторжном труде 1778 г., Пенитенциарного акта 1779 г.

Ключевые слова: Великобритания; социальные реформы; тюрьма; транспортация; одиночное заключение; каторжный труд; Пенитенциарный акт 1779 г.

Постановка проблеми. Криза інституту тюремного ув'язнення у сучасній пенології спонукає до пошуку більш ефективних та соціально прийнятних, як з гуманістичних, так і економічних засад, засобів впливу на правопорушників. За 200 років свого існування в'язниця в умовах капіталістичних відносин хоча і трансформувалася, але, здається, не виправдала покладених на неї сподівань: вона не виправляє, не привчає до праці, не перевиховує, тривала ж ізоляція лише унеможливлює подальшу соціальну адаптацію. 
Українські реалії в місцях позбавлення волі та менеджмент сфери виконання покарань, попри «євроінтеграційно-гуманістичні» гасла, скоріше відносять нас у «темні часи» англійських середньовічних тюрем, про які писав Дж. Говард. Історичного фльору також додає намагання, поки що неофіційно, перейменувати кримінально-виконавчу службу $\mathrm{y}$ «пенітенціарну». 3 вуст можновладців у публічному просторі сфера виконання покарань все частіше іменується «пенітенціарною» або ж лагідно - «пенітенціаркою».

Думається, таке легковажне використання історичних термінів і понять стало можливим у ситуації, коли не лише у вітчизняній, але й у всій пострадянській історіографії, досить мало уваги приділяється витокам інституту тюремного ув'язнення, історико-правовим дослідженням умов, етапів та наслідків становлення «нової» тюрми. І як результат - нерозуміння логіки, правил і законів розвитку цього виду покарання та засад його виконання.

Історія формування концепту виправного покарання в умовах ізоляції могла б стати тим міцним фундаментом, який дав би змогу розробити на теоретичному рівні концепцію реформування системи виконання покарань з урахуванням конкретно-історичних, суспільнополітичних та економічних умов.

Великій Британії належить першість щодо впровадження терміну «пенітенціарний». Англійськими філософами й правниками ще $\mathrm{y}$ XVIII ст. сформовано цілісний концепт виконання покарання у виді позбавлення волі та закріплено його нормативно. Саме тому, в аспекті дослідження витоків пенітенціарних систем Європи та Північної Америки, ідеї, концепції англійських тюремних реформаторів, а також етапи тюремних перетворень у цій країні становлять значний науковий інтеpec. У поодиноких роботах з історії тюремних систем, переважно дореволюційних російських авторів, єдиним реформатором тюрем у кінці XVIII ст., не лише у Британії, а й загалом в Європі, представлено Дж. Говарда. Хотілося б увести у цю «моноп'єсу» й інших акторів, визначивши їх роль у процесі тюремних перетворень.

Аналіз останніх досліджень і публікацій. Брак вітчизняних досліджень $з$ історії англійської тюремної реформи компенсується широкою зарубіжною, переважно англомовною науковою літературою, як монографічного характеру, так і окремими статтями. В основу даної розвідки лягли першоджерела, зокрема роботи ідеологів тюремних перетворень Вільяма Iдена (William Eden), Семюеля Денна (Samuel Denne), Джонаса Хенуея (Jonas Hanway), Джеремі Бентама (Jeremy Bentham), Джона Говарда (John Howard) та ін., а також акти парламенту 1774, 1776, 1779, 1784 рр. Аналіз основних положень законопроєкту про каторжні роботи 1778 p. (Hard Labour Bill) проведено на основі тексту, вміщеного у праці Дж. Бентама «A View of the Hard Labour Bill».

Цінним джерелом стали праці 3 історії англійської тюремної адміністрації Б. Уебб (B. Webb) i С. Уебб (S. Webb) [1], Ш. Мак-Конвіла (S. McConville) [2], дослідження впливу протестантської ідеології на реформування тюрем Л. Тронесс (L. Throness) [3], дисертаційні роботи Ф. Хардман (P. Hardman) і В. С. Балч- 
Ліндсей (V.S. Balch-Lindsay) [4;5], стаття Е. Дж. Дрейпера (А. J. Draper), присвячена ідеям та поглядам В. Ідена [6], та грунтовна розвідка витоків Пенітенціарного акта 1779 р. С. Деверо (S. Devereaux) [7]. У процесі дослідження ми також спиралися на класичні праці з окресленої проблематики: М. Ігнатьєва (M. Ignatieff), Д. Мелоссі (D. Melossi) та М. Паваріні (M. Pavarini) [8; 9].

Постановка завдання. Проаналізувати суспільно-політичні умови, що стали причиною перегляду англійської системи покарань, передумови та етапи тюремних перетворень у Великій Британії у 70-х роках XVIII ст., визначити основні положення нормативно-правових актів, що закріплювали ці зміни, окреслити ідеї та погляди філософів, релігійних діячів і правників щодо модернізації тюрем та їх вплив на розробку концепту виправного покарання як на теоретичному, так і нормативному рівні.

Виклад основного матеріалу. Велика Британія у другій половині XVIII ст. гостро відчувала негативні наслідки стрімкого індустріального розвитку: зубожіння населення, збільшення чисельності міської бідноти, бродяжництво й проституція, ріст злочинності тощо. I це за відсутності дієвих засобів боротьби з ними. Крім, звичайно, покарань. Але кримінальні закони Англії та Уельсу залишалися архаїчними й викликали справедливі нарікання, не так через свою жорстокість, як через неефективність. I хоча смертна кара передбачалася більш ніж за 200 злочинів (від вбивства до дрібних крадіжок), заради справедливості, слід зазначити, що призначалася вона, особливо у провінційних графствах, не так вже й часто. Грабіжників, злодіїв та шахраїв засуджували переважно до транспортації (висилки) за межі країни. Ї̈̈ можна було уникнути, направившись у діючу армію [7, p. 408].

Англійські дисиденти, громадські діячі та філантропи виступали за широкі соціальні реформи, скасування смертної кари, рабства та боргових тюрем, повсякчас звертаючи увагу на соціальні вади та хвороби й шукаючи шляхи їх подолання: поліпшення умов праці найманих працівників, опіка над сиротами, дотримання гігієни та відповідних норм утримання в лікарнях, робітних будинках і тюрмах.

3 початком руху за соціальні реформи все частіше поставало питання перегляду карної політики держави. Ця проблема стала предметом широкого обговорення після публікації 1767 р. англійською праці Чезаре Беккаріа «Про злочини і покарання» та видання Вільямом Блекстоном (William Blackstone) чергового тому коментарів англійських законів 3 цитатами Ч. Беккаріа. Як слушно зазначає Е. Дрейпер, те, як гаряче було підтримано ідеї Ч. Беккаріа в Англії, якої популярності набула його маленька книжечка, наочно ілюструє міру невдоволеності англійською практикою покарань [10, p. 179-180].

1770 року сформовано парламентський комітет на чолі 3 В. Блекстоном для перегляду системи покарань. I хоча, кардинальних змін не відбулося, це стало початком на шляху зміни вектору кримінальної політики та перегляду «Кривавого кодексу». 31771 року судді все частіше стали призначати покарання у виді тюремного ув'язнення [7, p.409]. Упродовж наступних років 
дискусії щодо гуманізації системи покарання лише актуалізувалися. Але виникло питання: чим замінити смертну кару за майнові злочини, щоб покарання було достатньо суворе й справедливе?

Сучасні дослідники, говорячи про значний вплив ідей Ч. Беккарія на формування доктрини англійського кримінального права, наголошують на тісному зв'язку континентальних дискусій щодо принципів та видів покарання з англійським дискурсом [10, p. 179-180]. Це, в першу чергу, бачимо у творі В. Ідена «Принципи карального права» 1771 р. [11]. Автор виступав проти смертної кари за майнові злочини та стверджував, що кримінальний закон має більшою мірою захищати, ніж карати. Антисуспільну поведінку не можна надовго приборкати надмірним застосуванням насильства з боку держави. При призначенні покарання пропонувалося виходити з міркувань «природної справедливості» і «суспільної користі», співвідносячи суворість санкцій з тяжкістю злочинів.

Вільям Іден висловлював сумніви щодо ефективності транспортації та критично ставився до тюремного ув'язнення, особливо боржників, яких вважав скоріше знедоленими, ніж злочинцями. Він також вказував на несправедливість попереднього ув'язнення: вина підслідного ще не доведена, а він уже опиняється в тюрмі, й наполягав на окремому утриманні підсудних і підслідних. В. Іден звертав увагу на численні недоліки англійських тюрем і вважав, що «позбавлення волі, призначене за законом як покарання, не відповідає принципам розумного законодавства і призводить до того, що засуджені стають тягарем для суспільства, ізоляція зажди погано впливає на їх моральні якості, крім того таке покарання не $є$ повчальним для інших, оскільки засуджені сховані за тюремними стінами» [11, p. 44].

Загальноєвропейські тенденції гуманізації покарань, а також зусилля громадських та релігійних діячів щодо подолання соціальних хвороб, в останній третині XVII ст. у Великобританії були тісно пов'язані з ліберальним рухом за модернізацію тюрем. На початку 70-х років він об'єднав протестантських проповідників, заможних філантропів, правників, лікарів, депутатів парламенту та лідерів місцевих громад. Найвідоміший нам тюремний реформатор Джон Говард та його інспекція англійських тюрем у 1773-1774 рр. були частиною процесу підготовки грунту для системних перетворень.

Депутати від Бедфордшира в Палаті громад Роберт Хенлі Онглі (Robert Henley Ongley) та Самуель Вітбрід (Samuel Whitbread) (останній був давнім приятелем Дж. Говарда - O.C.) 1773 р. подали на розгляд парламенту акт, що надавав право місцевим суддям наймати за певну платню священників для опіки в тюрмах. 3 ініціативи цих депутатів Дж. Говард був призначений шерифом Бедфордшира й розпочав активну діяльність 3 інспектування тюрем [12].

У досліджуваний період основними місцями позбавлення волі для правопорушників у Великій Британії залишалися місцеві тюрми (Goals), що перебували у віданні шерифів, та виправні будинки (Bridewell), підпорядковані мировим суддям. У перших утримували під вартою обвинувачених та підсудних; засуджених до 
смертної кари чи транспортації - до виконання вироку; засуджених до тюремного ув'язнення та боржників (для останніх у великих містах існували окремі боргові тюрми).

Засуджених мировими судами до покарання у виді позбавлення волі з примусовими важкими роботами (hard labour) утримували у виправних будинках. На практиці умови утримання в них майже не відрізнялися від тюрем. Покарання мало на меті лише ізоляцію в таких умовах, що б злочинець не бажав знову повернутися до виправного будинку. Примусові роботи у виправних будинках, що були частиною передбаченого вироком покарання, майже не організовувалися, через відсутність відповідного нагляду та осторогу довірити засудженим інструменти. Замість продуктивної праці засуджені у виправних будинках активно грали в азартні ігри, вживали алкоголь, придбаний у наглядачів, спілкувалися з жінками тощо [13, р. 554555]. Крім жахливих умов утримання, які відмічали інспектори тюрем і виправних будтинків, вони звертали увагу й на неорганізованість тюремного режиму та неефективність такого покарання.

Інспекції тюрем зазвичай здійснювали представники релігійних та благодійних товариств. Місцева ж влада, на яку покладалися обов'язки по інспектуванню в'язниць, навідувалася туди не часто. Спалахи «тюремної лихоманки» робили це місце вкрай непопулярним, тісно пов'язаним 3 хворобами та смертю. Шерифи нерідко думали, якщо зайдуть до тюрми, то після цього незабаром потраплять до могили. Тюремники ж навмисне культивували ці загрози, що б позбутися зайвого контролю та нагляду. Членів сімей засуджених такі загрози не лякали й дружини разом $з$ дітьми могли роками проживати за тюремними гратами разом 3 ув'язненим главою сімейства [14]. Тому інспекції тюрем Дж. Говарда як шерифа не могли залишитися непоміченими.

У лютому 1773 р. депутат Палати громад від Тонтона, адвокат Олександр Пофем (Alexander Popham), у графстві якого упродовж XVIII ст. десятки людей (судді, засуджені й прості громадяни) загинули від «тюремної лихоманки», ініціював скасування норми про обов'язкову сплату мита за звільнення 3 в'язниці [15]. Однак депутати не підтримали його ініціативи.

Довідавшись про діяльність Дж. Говарда, О. Пофем запросив його виступити перед депутатами зі звітом про стан тюрем. Доповідь Дж. Говарда справила враження i пришвидшила підготовку законодавчих змін. До розробки відповідних актів долучилися, крім О.Пофема, уже згаданий С. Вітбрід, а також Джон Сент-Джон (John St John) близький приятель В. Ідена [2, р. 86].

15 березня 1774 р. Парламент ухвалив так званий Тюремний акт (Gaol Act). Фактично це були два документи: The Discharged Prisoners Act i Health of Prisoners Act [2, p. 86-87]. Перший скасував тюремне мито для тих ув'язнених, які були виправдані судом. Компенсацію тюремникам за утримання у розмірі 13 шилінгів 4 пенсів повинен був сплачувати місцевий суд. Другий акт надавав суддям широкі повноваження контролю за тюремною адміністрацією щодо забезпечення гідних умов ув'язнення, норм гігієни, вентиляції камер, окремого утримання хворих 
в'язнів і надання їм медичної допомоги (задля цього при тюрмах мали бути лікарі або аптекарі, послуги яких оплачувала б місцева влада) [2, p. 87; 16, p. 7].

I хоча Дж. Говард власним коштом розіслав копії цих актів у кожну тюрму, судді й тюремники, здебільшого, ігнорували їх. Місцева ж влада, у компетенції якої перебували тюрми, місця попереднього ув'язнення та виправні будинки, не поспішала витрачати кошти на покращення умов утримання.

У цей період проблемами місць ув'язнення опікувалися здебільшого приватні благодійники та релігійні товариства, переважно методисти та квакери. Достатньо активно до філантропічної діяльності та професійної допомоги ув'язненим долучилися відомі лондонські лікарі, що виступали за широкі соціальні реформи: засновник Лондонського медичного товариства Джон Летсом (John Coakley Lettsom) i Джон Фозергілл (John Fothergill). Значні кошти на викуп боржників з в'язниць виділяв промисловець, благодійник, приятель Дж. Говарда та Дж. Хенуея, Piчард Рейнольдс (Richard Reynolds). Після смерті останнього було встановлено пам'ятний камінь 3 іменами Дж. Говарда, Дж. Хенуея, Дж. Фозергілла та Р. Рейнольдса 3 вдячною епітафією за те, що вони «пом'якшували горе людей» [17, p. 12]. Більшість цих благодійників належали до релігійного Товариства друзів (квакерів).

Усе те, що англійські інтелектуали хотіли впровадити у результаті соціальних реформ: створення національного реєстру громадян, відкриття загальних лазень для підтримання гігієни, запобігання епідемічним хво- робам, організація безкоштовних шкіл для дітей бідноти, скасування рабства та смертної кари, вони переносили й у новий концепт тюрми.

Цікавою видається теза, що не стільки потреби держави чи ії кримінальна політика вплинули на реформу тюрми, як постійні епідемії серед тюремного населення, які нерідко були загрозою для усього міста, що i змусило лікарів, філантропів та релігійних діячів опікуватися реформою місць ув'язнення [18, p. 15-16].

Більш масштабно причини соціальних перетворень, у контексті яких відбувалась модернізація тюрем, розглядали М. Фуко та М. Ігнатьєв, вважаючи, що тюремна реформа ставила за мету не так покращення стану тюрем і становища засуджених, як була частиною плану все більш впливового середнього класу щодо організації, контролю й обмеження найнижчих прошарків населення [19, p. 232]. Для процвітання і зміцнення своїх позицій на міжнародній арені Британія потребувала працьовитих і дисциплінованих громадян. Саме переконаність методистів і квакерів, що праця і релігійне навчання - найкращий засіб реформування трудящих мас, спонукала їх до активної благодійної діяльності [20, р. 311].

Не варто забувати, що стрімкий розвиток виробництва в Англії зумовив і пошук нових ідей щодо менеджменту робочої сили: впровадження суворих правил дисципліни на виробництві, чіткої регламентації робочого часу й оплати праці, системи заохочень і штрафів. Надалі все це буде використано і в системі виконання покарання [8, p. 35-36].

Для організації девіантних елементів мали б бути створені такі 
місця утримання, де б панувала продуктивна системна праця, сувора дисципліна, контроль та релігійне виховання. В Англії вже існували виправні будинки 3 примусовими роботами (hard labor), але свої функції вони не виконували: скупчення злочинців під одним дахом без суворої дисципліни та роздільного утримання, перетворювало такі місця ув'язнення на осередки розпусти, ледарства та «школи» злочинності. Отже, потрібні були нові методи впливу.

1758 року економіст Джозеф Macci (Joseph Massie), пропонуючи план побудови мережі благодійних та промислових будинків для організації роботи збіднілих мас, зазначав, що бідноту все більше вражає вірус розкоші й аморальності, тому так важливо створити окремі «будинки ізоляції та виправлення» (House of Confinement and Correction) для тих, хто не бажає чесною працею заробляти собі на життя. Основою «лікування» цих вад автор називав важку працю та відшкодування збитків i, як приклад, наводив досвід голландських виправних будинків [21, р. 119].

Релігійні діячі, зокрема єпископ Джозеф Батлер (Joseph Butler) у проповіді 1740 р., акцентували увагу на покаянні й виправленні як кінцевому результаті процесу покарання [40, p.86]. Задля найбільш ефективного досягнення цієї мети все частіше пропонувалося впровадити одиночне ув'язнення [6, р. 124]. Так, у «Листі преподобного Семюеля Денна лордмеру Лондона Роберту Ледброку» (1771 р.) [22] автор обгрунтовував доцільність і корисність одиночного тюремного ув'язнення ${ }^{1}$. Його безперечним плюсом С.Денн вважав те, що за таких умов злочинці не могли б негативно впливати один на одного, а також це унеможливлювало б розповсюдження хвороб та епідемій. «Не можна не погодитися з тим, що товариство є однією з головних утіх для людини, - писав С. Денн, - і те, що людина має бути цілковито на самоті, для неї може бути нестерпним, але інколи, самотність - найкраще товариство» [22, р. 63]. Значні витрати, що їх потребувала організація одиночних тюрем, автор вважав адекватною ціною за «зцілення» правопорушників та повернення їх до законослухняного життя.

Однак, ідея одиночного ув'язнення не була аж такою новою. Одним із перших її висловив Томас Брей (Thomas Bray) в есе 1702 p. [23]. 1725 року англійський філософ голландського походження Бернард Мандевиль (Bernard Mandeville), описуючи вади англійських місць ув'язнення (п'янство, розпуста, азартні ігри, негативний вплив злочинців один на одного, відсутність духовної опіки), пропонував у тюрмі Ньюгейт побудувати сотню одиночних камер розміром 12 футів 3 мінімальним освітленням й аскетичними умовами перебування для найзапекліших злочинців, а також засуджених уперше [24, р. 16-18, 38].

Цілісний концепт тюрми «нового зразка», у якому системі одиночного ув'язнення відводилася ключова роль, розробив та обгрунтував Джонас Хенуей у роботах «The Defects of Police» (1775 p.), «Solitude

1 Саме тоді планувалося переоблаштування лондонської тюрми Ньюгейт і С. Денн виступив з власною пропозицією щодо одиночних камер [40, p. 87].

(C) Сокальська О. В., 2019 
in Imprisonment: With Proper Profitable Labour and a Spare Diet, the Most Humane and Effectual Means of Bringing Malefactors» (1776 p.) та «Distributive Justice and Mercy» (1781 p.). Автор визначив вимоги до будівлі в'язниці та їі розташування, порядок відбування покарання, певний режим утримання з метою покаяння, перевиховання та пристосування злочинців до соціально корисного життя, вважаючи найбільш ефективним, в аспекті досягнення зазначеної мети, одиночне утримання. Це давало б можливість засудженому більше заглибитися у свій внутрішній світ, переоцінити свої моральні установки. Ідеальну, на думку Дж. Хенуея, тюрму, де душа людини змінювалася б, він назвав реформаторієм. Особлива роль відводилася священнику, який би регулярно відвідував засуджених і слідкував за їх виправленням $[25 ; 26]$.

Як бачимо, у середині 70-х років XVIII ст. у Британії на теоретичному рівні сформувався новий тюремний дискурс, але не було нагальної потреби й політичної волі впроваджувати ці ідеї в життя.

Питання призначення та виконання покарання актуалізувалося 3 початком війни за незалежність Північно-Американських колоній. Відправка засуджених до транспортації за океан стала неможлива (скасована 1775 р. - О.С.) і це внесло хаос у всю систему покарань. Щороку необхідно було шукати місця для розміщення 1000 таких засуджених [27]. Тюрми ж графств, у яких до цього перебували переважно боржники та підслідні, швидко стали переповнені.

Уряду довелося спішно шукати вихід 3 критичної ситуації. В. Іден запропонував розміщати засуджених до транспортації на кораблях, що раніше перевозили злочинців до колоній. Ще 1775 p. близько 900 засуджених помістили на судна «Цензор» і «Юстиція», пришвартовані у Вулвічі [28, р. 373; 29, p. 334]. Їх утримували замкненими в трюмі, а вдень використовували на роботах в доках, на арсеналі, по розчищенню Темзи тощо. Планувалося, що після припинення війни, транспортація буде відновлена, тому такі заходи вважалися тимчасовими. Управління тюрмами-кораблями або халками (від анг. «hulk») та організація робіт була передана підприємцю Дункану Кемпбеллу (Duncan Campbell), що донедавна займався організацією транспортації [29, p. 334].

1776 року парламент ухвалив рішення, про заміну транспортації позбавленням волі, поєднаним 3 каторжними роботами. Відповідний законопроєкт розробив В. Іден, який на цей час займав високу посаду в уряді. 3 моменту видання «Принципів карального права» у 1771 p. В. Іден, залишаючись прихильником каторжних робіт, дещо переглянув своє негативне ставлення до тюремного ув'язнення як виду покарання, ймовірно, під впливом теоретичних розробок Дж. Хенуея та позитивного європейського досвіду. Так, Е. Дрейпер зауважує, що оперативність, з якою В. Іден розробив схему заміни транспортації позбавленням волі, пояснюється, скоріш за все, його знайомством $з$ оглядами діяльності континентальних виправних закладів в Амстердамі, Римі та Генті, зібраними впродовж 1771-1775 pр. [6, p. 125]. Нове покарання мало бути достатньо суворим, крім того слід було вирішити питання розміщення 
засуджених та їх використання 3 користю для суспільства.

«Акт, що дозволяє на певний час покарання каторжними роботами для злочинців, засуджених за окремі види злочинів до транспортації у будь-яку з колоній Його Величності» [30], більш відомий як Акт про халки (Hulks Act) (хоча в тексті про плавучі тюрми навіть не згадується - O.C.) або Акт про каторжні роботи (Hard Labour Act) був ухвалений у травні 1776 р. Відповідно до нього, засуджені до транспортації, переважно за майнові злочини, повинні були відбувати покарання у виді позбавлення волі у поєднанні 3 важкою працею (по розчистці річки Темзи), строком від 3 до 10 років. Жінки-засуджені та чоловіки, які не могли працювати на таких роботах, утримувалися б у виправних будинках (House of Correction).

Закон детально регламентував: процедурні питання призначення покарання та передачі засуджених тюремникам (усі видатки пов'язані 3 цим покривалися округом чи містом); їх використання лише на чітко визначених роботах; харчування та одяг засуджених (їх слід було годувати хлібом та мізерною їжею, давати воду чи пиво, одягнені вони були в каторжну робу, жодної іншої їжі чи одягу не дозволялося). А також визначав покарання: за відмову виходити на роботи чи порушення правил утримання - побиття батогом, за спробу втечі - штраф, за втечу, вчинену вперше, строк каторжних робіт збільшувався вдвічі, за повторну смертна кара.

у законі вперше закріплено норми про виправлення як кінцевий результат покарання та простежується турбота законодавця про долю засудженого після відбування покарання, про що свідчать такі приписи: 1) якщо поведінка злочинця демонструє ознаки виправлення, то тюремна адміністрація може звернутися до державного секретаря з проханням проявити милосердя і зменшити строк ув'язнення; 2) після завершення строку покарання засуджений отримував частину зароблених ним грошей (від 40 шилінгів до 5 фунтів) (п. IX) [30].

Вільямом Іденом було не лише розроблено норми про тимчасову заміну транспортації, а, фактично, створено правову основу нового виду покарання - позбавлення волі, поєднаного 3 каторжною працею. Відбувати це покарання засуджені до транспортації повинні були у плавучих тюрмах (халках).

Якщо тюремні реформатори загалом прихильно поставилися до ідеї плавучих тюрем та каторжних робіт, оскільки вважали транспортацію, а тим більше смертну кару, неефективними покараннями й активно шукали їм заміну, то серед парламентарів було достатньо противників цього нововведення. Вони наполягали на відновленні транспортації в Канаду та Нову Шотландію [31, р. 24].

У перший рік функціонування халків смертність серед засуджених була надзвичайно високою, а умови утримання жахливими. Однак, упродовж наступного року ситуація дещо покращилася. За результатами інспекцій халків, одну з яких провів Дж. Говард, парламентарям подали звіт про доцільність використання халків у майбутньому, у разі покращення умов утримання [5, p. 211].

Неможливість висилки значної маси засуджених за межі країни, ак- 
туалізувала проблему реформування системи покарань та привернула увагу широких кіл громадськості до умов утримання як у халках, так і тюрмах. Цьому сприяло й поширення в суспільстві інформації про стан тюрем.

1776 року детальний опис умов утримання у тюрмах Лондона й околиць, а також халках, опублікував лікар лондонського виправного будинку Вільям Сміт (William Smith). Інспекція тюрем була проведена ним на прохання одного $з$ благодійних товариств [4, р.137]. Ця праця, крім описів місць ув'язнення, також містила конкретні пропозиції щодо покращення режиму утримання: організації обов'язкових прогулянок ув'язнених, облаштування просторих камер тощо [33].

y наступній праці «Mild punishments sound policy or observations on the laws relative to debtors and felons...» (1778 р.) В. Сміт виклав погляди на систему покарання правопорушників і боржників. Автор закликав бачити в злочинці перш за все християнина, «брата, що збився зі шляху», якого слід спонукати покаятися й виправитися, а не знищувати його. В.Сміт зазначав, щоб зробити людину чесною, ви повинні спочатку дати їй справедливе відчуття Бога й віри, без чого неможливо досягти порядку та гармонії в суспільстві. Для цього у кожній тюрмі слід було ввести посаду штатного священника, який би давав релігійні настанови, читав проповіді, проводив спільні богослужіння [3, p. 143]. Найбільш ефективним покаранням В. Сміт вважав тюремне ув'язнення, поєднане 3 каторжними роботами [34, p.2]. Також він наполягав, що розумне й своєчасне виявлення незначних право- порушень і виправлення таких злочинців запобігатиме вчиненню більш тяжких злочинів [34, р. 13].

Але найбільше на подальший перебіг тюремних реформ як в Британії, так і за її межами вплинула праця Дж. Говард «Стан тюрем в Англії та Уельсі» («The State of the Prisons in England and Wales»), опублікована 1777 p.

Дж. Говард упродовж 17731776 рр. провів масштабну роботу по збору даних з питань функціонування тюрем та умов утримання у них. Його зацікавленість тюрмою зумовлена не намаганням знайти альтернативу смертній карі чи транспортації, а глибокою релігійністю та співчуттям до засуджених, що страждали в ув'язнені [35, р. 567]. Автор детально описав реальний стан в'язниць у державі, зловживання тюремників та жалюгідне становище засуджених. У своїй праці він пропонував конкретні шляхи покращення устрою тюрем. Книга була високо оцінена сучасниками і справила ефект - питання модернізації тюрем перестало бути виключно турботою філантропів і релігійних діячів. Саме завдяки Дж. Говарду проблеми функціонування тюрем стали предметом широкого суспільного інтересу й були донесені до парламентарів. Не випадково, на першій сторінці книги зазначалося: «Високоповажній Палаті громад на знак подяки за підтримку проєкту й за честь, надану автору, ця книга шанобливо написана їх відданим слугою» [36].

Парламентський комітет під головуванням Чарльза Бенбері (Charles Bunbury), з огляду на тимчасовий характер Акта про халки 1776 р., що ухвалювався на 2 роки, продовжив роботу по урегулюванню 
питання відбування покарання засудженими до транспортації. До обговорення концепції покарання, яке б замінило смертну кару за майнові злочини та транспортацію долучилися В. Іден, В. Блекстон, Ч. Бенбері, Г. Елліот (Gilbert Elliott) та інші [1, p. 38].

Упродовж двох наступних років В. Іден працював над підготовкою законопроєкту про каторжні роботи (Hard Labour Bill). Використавши ідеї теоретиків тюремних перетворень про одиночне утримання й релігійний вплив, а також позитивний досвід організації тюремних робіт в європейських виправних установах, В. Іден розробив систему виконання та відбування покарання у виді позбавлення волі, поєднаного з каторжною працею, у спеціальних установах - будинках каторжних робіт.

У преамбулі автор виклав загальні положення, причини та мету створення каторжних тюрем, вказавши на неможливість транспортації, непридатність місцевих тюрем для відбування довгострокового ув'язнення та необхідність впровадження більш ефективних видів покарання (ст. 1) [37]. Англію та Уельс пропонувалося поділити на 19 округів й у кожному відкрити будинок каторжних робіт (Houses of Hard Labour), відокремлений від інших місць ув'язнення.

Засади організації каторжних робіт, закріплені Актом про халки 1776 р., у законопроєкті набули більшої деталізації й розробки: встановлено вимоги до будівель каторжних тюрем, регламентовано питання умов і режиму відбування покарань, в основу якого покладено роздільне утримання засуджених в одиночних камерах вночі та їх спільні роботи під суворим наглядом. Контроль за діяльністю каторжних тюрем повинні були здійснювати спеціальні комітети й інспектори-візитери. У проєкті було чітко визначено штат тюремних службовців каторжних в'язниць, до складу якого обов'язково б входили лікар (аптекар) і священник.

Чоловіки повинні були утримуватися окремо від жінок; кожен засуджений повинен був мати осібну камеру; жодній особі, крім представників адміністрації, капелана або інспектора-візитера не дозволялося заходити до камери, зустрічатися з засудженим та спілкуватися 3 ним. Передбачався поділ усіх засуджених на 3 класи, в кожному з яких вони повинні були перебувати рівний відрізок призначеного строку покарання. Планувалося, що зведені коштом місцевих громад, в майбутньому каторжні тюрми будуть утримуватися за рахунок прибутків 3 каторжних робіт. Окрема стаття законопроєкту регламентувала духовну опіку та релігійне виховання засуджених.

Отже, традиційна для англійської системи покарань каторжна праця (hard labour) у проєкті Hard Labour Bill B. Ідена отримала «нове життя» і була доповнена роздільним одиночним утриманням, суворим наглядом та релігійним вихованням.

Парламент не затвердив законопроєкт В. Ідена, продовживши дію Акта про халки 1776 р. ще на рік [7, p. 423-424]. I це незважаючи на те, що 3 серпня 1776 р. по березень 1778 р. $з 6$ тисяч ув'язнених плавучих тюрем померло більше тисячі [2, p. 107]. Підтримка парламентарями транспортації та халків не в останню чергу була пов'язана зі значним політичним впливом Д. Кемпбелла - 
управляючого халками і, донедавна, підрядника виконання транспортації $[40$, p. 57$]$.

1779 року на розгляд парламенту було представлено новий Penitentiaries Bill, в основу якого лягли положення проєкту В. Ідена 1 , доповнені В. Блекстоном нормами про відновлення транспортації та збереження халків для самих запеклих злочинців. Зміни було внесено задля того, щоб ідея впровадження каторжних тюрем була легітимізована парламентарями. В. Блекстон запропонував термін «пенітенціарні» для позначення експериментальних будинків ув'язнення та каторжної праці, сподіваючись на позитивні зміни, які будуть відбуватися у результаті їх запровадження, а також, щоб показати, що вони якісно різняться від інших місць ув'язнення [7, р. 429]. Це й дало назву законопроєкту.

Пенітенціарний акт (Penitentiary Act) ухвалено Парламентом у квітні 1779 р. [38]. На відміну від Hard Labour Bill 1778 р., він не передбачав упровадження системи каторжних тюрем по всій країні, а лише 2-х загальнодержавних експериментальних пенітенціарних будинків (Penitentiary Houses): на 600 місць для чоловіків та на 300 - для жінок, за кошти, виділені парламентом.

Одиночне ув'язнення в пенітенціарному будинку, як зазначалося в статті 5, поєднане з систематичною працею та релігійними настановами, повинно не лише утримувати інших від вчинення злочинів, а виправляти їх та привчати до праці.

Щодо засад діяльності та режиму утримання у пенітенціарних будинках акт 1779 р. зберіг норми Hard Labour Bill 1778 р. Зокрема ті, що визначали: вимоги до будівлі тюрми, штат тюремних службовців, умови та режим утримання, основою якого було одиночне утримання i важка, виснажлива каторжна праця, перелік дисциплінарних стягнень та заохочень, поділ засуджених на 3 класи, обов'язковість відвідин богослужінь та духовної опіки зі сторони тюремного священника. Нагляд за діяльністю пенітенціарних будинків повинен був здійснювати спеціальний комітет та місцеві суди.

Пенітенціарний Акт 1779 р. було ухвалено на 5 років, упродовж яких експеримент з пенітенціарними будинками мав би бути реалізований. Задля цього було призначено трьох інспекторів-кураторів проєкту: Дж. Говарда, Дж. Фозергілла та відомого філантропа Дж. Уайтлі (George Whately). Вони мали підшукати земельну діяльну під будівництво, укласти необхідні контракти та контролювати процес зведення пенітенціарних будинків. Однак, майже відразу розпочалися суперечки щодо місця їх побудови: Дж. Говард i Дж. Фозергілл наполягали на Іслінгтоні, передмісті Лондона, Дж. Уайтлі вважав, що більше підходить Лаймхауз [2, р. 108]. Упродовж 1780 р. так i не вдалося досягнути згоди. Автор ідеї покарання у виді позбавлення волі, поєднаного з каторжними роботами, В. Іден відбув у Дублін, а натхненник Пенітенціарного акта В. Блекстон тяжко захворів і невдовзі помер [3, р. 152-153].

Після смерті Дж. Фозергілла у грудні 1780 р. Дж. Говард залишив

1 В. Іден у цей час перебував у США з дипломатичною місією. 
посаду інспектора. На початку 1781 р. призначено нових інспекторів: Г. Елліота, Ч. Бенбері та Т. Баудлера (Thomas Bowdler). Вони швидко підшукали земельну ділянку в Battersea Rise і провели конкурс на кращий проєкт пенітенціарного будинку, в якому переміг архітектор В. Блекборн. Однак казначейство відхилило заявку на отримання коштів для початку будівництва, запланованого на вересень 1782 р., мотивуючи це тим, що незабаром будуть ухвалені нові види покарань, що зробить питання побудови пенітенціаріїв неактуальним [2, p. 108-109].

1784 року парламент відновив транспортацію [39]. А 1787 р. перші кораблі з засудженими рушили до Австралії, де в Ботані Бей (Botany Вау) було вирішено заснувати колонію для зсильних.

Цим і завершився початковий етап тюремних перетворень як частини соціальних реформ. Упродовж нього, крім загального руху за покращення умов утримання в тюрмах, активістами якого були англійські дисиденти та філантропи, сформовано концепт покарання у виді позбавлення волі у поєднанні з примусовою працею та релігійним впливом, однією з цілей якого визначено виправлення злочинця. Передбачалося не так реформування діючих місць ув'язнення, як створення якісно нових установ для відбування покарання, відмінних від звичних місцевих тюрем: Дж. Хенуей назвав їх реформаторіями, В. Іден - будинками каторжної праці, В. Блекстон - пенітенціарними будинками. Тюремні реформатори оптимістично сподівалися, що за умови відповідного тюремного режиму (роздільного одиночного утримання, суворого нагля- ду й дисципліни, систематичної праці та релігійної опіки) навіть найзапекліший злочинець може виправитись і надалі інтегруватися у суспільство [41, р. 3].

Висновки. Велика Британія в останній третині XVIII ст., переживаючи стрімкий індустріальний розвиток, стикнулася зі значними соціальними проблемами: зубожіння населення, зростання рівня злочинності й потребою в організації трудових мас. Карна політика держави, попри суворість покарань, на практиці була досить неефективною. Англійські дисиденти, громадські діячі та філантропи виступали за широкі соціальні реформи, скасування смертної кари, рабства та боргових тюрем. 3 початком руху за соціальні реформи все частіше поставало питання перегляду карної політики держави в руслі загальноєвропейських гуманістичних тенденцій. Зусилля громадських і релігійних діячів щодо подолання соціальних хвороб були тісно пов'язані 3 ліберальним рухом за модернізацію тюрем.

У якості приватної благодійної ініціативи започатковано регулярні інспекції місць ув'язнення. У результаті поширення інформації про жахливий стан тюрем та зловживання тюремників депутатами Палати громад ініційовано ухвалення тюремних актів 1774 р., що скасовували тюремне мито для ув'язнених, виправданих судом, надавали суддям повноваження здійснювати нагляд за умовами утримання в тюрмах, передбачали обов'язкові регулярні відвідини тюрем лікарями, послуги яких оплачувала місцева влада (як засвідчила інспекція Дж. Говарда, станом на 1776 р. ці приписи виконувалися у 
більшості тюрем країни [36, p. 56, 148-210]).

У цей же період з'являються праці філософів і правників (С. Денна, В. Ідена, В. Сміта, Дж. Хенуея та ін.), у яких заперечується кара як єдина мета покарання й обгрунтовується необхідність упровадження нових більш гуманних та ефективних видів покарання в умовах ізоляції, акцентується увага на покаянні та виправленні злочинців, що найбільш ефективно може бути досягнуто в умовах одиночного ув'язнення. Загалом, сформувалося певне інтелектуальне коло «тюремних реформаторів»: філантропів, юристів, депутатів Парламенту й урядовців, які долучилися до нормативної розробки засад майбутніх тюремних перетворень.

Нагальна потреба в реформуванні англійської системи покарань виникла після початку війни американських колоній за незалежність, що унеможливило відправку туди засуджених до транспортації. Уряду спішно довелося шукати заміну висилці. Тимчасово ж засуджених утримували в плавучих тюрмах (халках).

Розробки теоретиків тюремної реформи знайшли нормативне закріплення в Акті про халки 1776 р. та Пенітенціарному акті 1779 р., в основу якого лягли положення законопроєкту про каторжну працю В. Ідена. У якості альтернативи транспортації пропонувалося запровадити покарання у виді позбавлення волі поєднане 3 каторжною працею, метою якого була не лише кара та залякування, а й виправлення злочинців, через усвідомлення своєї вини, покаяння та систематичну працю. Оновою режиму утримання мало бути розділення засуджених на класи, одиночне ув'язнення в нічний час, сувора дисципліна та духовна опіка.

Попри нереалізованість на практиці, Пенітенціарний акт 1779 р. мав важливе значення для подальшого удосконалення діяльності чинних місць ув'язнення і побудови нових тюрем по всій державі, однак у якості місцевої ініціативи, а не централізованої реформи, як це планувалося у 1778-1779 pр.

Упродовж 70-х років XVIII ст. тюремні перетворення були лише частиною загально-соціальних реформ, а не самостійним напрямком, оскільки кардинальнол зміни державної політики та системи покарань так і не відбулося. 1784 року відновлено транспортацію як основний вид покарання. Однак підгрунтя для масштабної тюремної реформи, як теоретичне, так і нормативне, було закладено. Значно змінилася правозастовча практика: кількість вироків місцевих судів, що передбачали тюремне ув'язнення, зросла на 20-30\%, а тюремне населення вдвічі [4, p. 6-7].

\section{References}

1. Webb, S., Webb, B. (1922). English prisons under local government. London: Longmans, Green.

2. McConville, S. A (1981). History of English Prison Administration: 1750-1877. Routledge \& Kegan Paul.

3. Throness, L. (2008). A Protestant Purgatory: Theological Origins of the Penitentiary Act, 1779. Aldershot: Ashgate Publishing, Ltd. 
4. Hardman, P. (2007). The Origins of Late Eighteenth-Century Prison Reform in England. (PhD thesis). Department of History. University of Sheffield.

5. Balch-Lindsay, V.S. (1998). An orderly metropolis: the evolution of criminal justice in London, 1750-1830. (A dissertation in history). Texas Tech University.

6. Draper, A. J. (2001). William Eden and leniency in punishment. History of Political Thought. Vol. 22, No. 1, 106-130.

7. Devereaux, S. (1999). The Making of the Penitentiary Act, 1775-1779. The Historical Journal. Vol. 42, No. 2, 405-433.

8. Ignatieff, M. (1981). The Ideological Origins of the Penitentiary. Crime and Society: Readings in History and Theory / Fitzgerald M., McLennan G., Pawson J. Routledge. P. 31-49.

9. Melossi, D., Pavarini, M. (1981). The Prison and the Factory. Origins of the Penitentiary System (Critical criminology series) / Translated by G. Cousin. London: The Macmillan Press LTD.

10. Draper, A. J. (2000). Cesare Beccaria's influence on English discussions of punishment, 1764-1789. History of European Ideas, 26, 177-199 https://doi.org/10.1016/S0191-6599(01)00017-1.

11. Eden, W. (1771). Principles of Penal Law. London.

12. Parliamentary Initiatives Motivated Howard's Prison Investigations. URL: http://www.acrosswalls.org/howard-prison-investigations/ (accessed: 21.11.2018).

13. Blake, O. W. (1919). Sir William Blackstone. Yale Law Journal. Vol. 28. Issue 6. P. 542-566.

14. Fear, Uncertainty, and Doubt about Gaol Fever URL: http://www.acrosswalls.org/ section/communicative-walls/knowledge/john-howard/ (accessed: 10.09.2019).

15. Discharged Prisoners Act of 1774. URL: http://www.acrosswalls.org/ notes/discharged-prisoners-act-of-1774/ (accessed: 10.09.2019).

16. Creese, R., Bynum, W. F., Bearn J. (1995). The Health of Prisoners: Historical Essays. Amsterdam and Atlanta, GA Rodopi.

17. Montgomery, J. (1817). Verses to the Memory of the Late Richard Reynolds, of Bristol. London.

18. Porter, R. (1995). 'Howard's beginning: prisons, disease, hygiene. Richard Creese, William F Bynum, J Bearn (eds). The health of prisoners: historical essays. Rodopi, Amsterdam \& Atlanta.

19. Page, A. (2003). John Jebb and the Enlightenment Origins of British Radicalism. Greenwood Publishing Group.

20. Harris, R. (2002). Politics and the Nation: Britain in the Mid-Eighteenth Century. OUP Oxford.

21. A plan for the establishment of charity-houses for exposed or deserted women and girls, and for penitent prostitutes: Observations concerning the Foundling-Hospital, shewing the ill consequences of giving public support thereto. Considerations relating to the poor and the poor's-laws of England. (1758). By J. Massie. London: printed for T. Payne; sold by W. Shropshire; W. Owen; and C. Henderson.

22. Reverend Samuel Denne's A letter to Sir Robert Ladbroke, Knt, Senior Alderman, And One of the Representatives of the City of London. (1771). London.

23. See: Sokalska, 0. (2018). Origins of English prison reform (XVI-XVIII centuries). Bulletin of the Penitentiary Association of Ukraine, 4(6), 16-29. https://doi.org/https: 10.34015/2523-4552.2018.4.02. [in Ukranian].

24. An Enquiry into the Causes of the Frequent Executions at Tyburn, ete, by B. Mandeville.(1725). 
25. Hanway, J. (1775). The Defects of Police, the Cause of Immorality, and the Continual Robberies committed, particularly in and about the Metropolis. London.

26. Hanway, J. (1776). Solitude in Imprisonment: With Proper Profitable Labour and a Spare Diet, the Most Humane and Effectual Means of Bringing Malefactors, who Have Forfeited Their Lives, Or are Subject to Transportation, to a Right Sense of Their Condition; with Proposals for Salutary Prevention. London: Printed for J. Bew.

27. Early American crime. The End of Convict Transportation: Convict Hulks. URL: http://www.earlyamericancrime.com/convict-transportation/end-of-

transportation/convict-hulks (accessed: 15.09.2019).

28. Durston, G. J. (2017). Fields, Fens and Felonies: Crime and Justice in EighteenthCentury East Anglia. Waterside P.

29. Hitchcock, T., Shoemaker, R. (2015). London Lives: Poverty, Crime and the Making of a Modern City, 1690-1800. New York: Cambridge University Press.

30. An act to authorise for a limited time the punishment by hard labour of offenders who for certain crimes are or hall become liable to be transported to any of his Majesty's colonies and plantations. The statutes at large from the Magna Charta, to the end of the Eleventh Parliament of Great Britain, anno 1761 [continued to 1806]. By Danby Pickering. By Great Britain; Pickering, Danby. T. 31. Cambridge. P. 262-269.

31. Lock, F. P. (2006). Edmund Burke. V. II: 1784-1797. New York: Oxford University Press.

32. The country justice: containing the practice, duty and power of the justices of the peace, as well in as out of their sessions by Dalton, Michael, d. 1648?; Adams, John, 17351826, former owner. BRL; John Adams Library (Boston Public Library).

33. State of the gaols in London, Westminster, and borough of Southwark : to which is added, An account of the present state of the convicts sentenced to hard labour on board the Justitia upon the river Thames, by William Smith, London: printed and sold by J. Bew. (1776).

34. Mild punishments sound policy or observations on the laws relative to debtors and felons, ... The second edition, with an appendix, wherein hard labour, substituted in place of transportation, is elucidated ... By William Smith, London: printed and sold by J. Bew. (1778).

35. Goldie, M., Wokler, R. (2006). The Cambridge History of Eighteenth-Century Political Thought. T. 1. Cambridge University Press.

36. Howard, J. (1777). The state of the prisons in England and Wales: with preliminary observations, and an account of some foreign prisons. Warrington: Printed by William Eyres.

37. Bentham, J. (1778) A View of the Hard Labour Bill. The Works of Jeremy Bentham, published under the Superintendence of his Executor, John Bowring (Edinburgh: William Tait, 1838-1843). Vol. 4, 3-35.

38. The Statutes at Large from the Magna Charta, to the End of the Eleventh Parliament of Great Britain, Anno 1761 [continued to 1806]. By Danby Pickering, T. 32. 1778. P. 417-445.

39. The Statutes at Large: From the Magna Charta, to the End of the Eleventh Parliament of Great Britain, Anno 1761 [continued to 1806]. By Danby Pickering. By Great Britain; Pickering, Danby. T. 34. Cambridge. P. 732-740.

40. Semple, J. (1990). Jeremy Bentham's Panopticon Prison. (Ph.D. thesis). London University.

41. Davie, N. (2013). When was the prison? Thinking and re-thinking the penitentiary in Britain, 1770-1850 (unpublished seminar paper) URL: https://www.academia.edu/ 3383786/_When_was_the_prison_Thinking_and_re-thinking_the_penitentiary_in_Britain _1770-1850_unpublished_seminar_paper_2013_(accessed: 25.10.2019). 
o. Sokalska, PhD in Law, Associate Professor

e-mail: co2001@ukr.net; ORCID ID:0000-0001-8737-0829

\section{"Aspiration for reform": prison transformations in the United Kingdom in the 70s of the 18th century}

The article analyzes the socio-political conditions that led to the revision of the English system of punishment, the causes and stages of prison transformations in the United Kingdom in the 70s of the 18th century. The author identifies the main provisions of the legislation that enshrined these changes, outlines the ideas and views of philosophers, philanthropists and lawyers (Samuel Denne, Jonas Hanway, William Eden, William Eden, William Blackstone, John Howard) on the modernization of prisons and their importance in developing the concept of correctional punishment. Particular attention is paid to the development process and the main provisions of the Gaol Act 1774, Hulks Act 1776, Hard Labor Bill 1778, Penitentiary Act 1779.

Developments of prison reform theorists were enshrined in the Hulks Act 1776 and the Penitentiary Act 1779. As an alternative to transportation, abolished in 1775 , it was proposed to impose hard labor imprisonment punishable, the purpose of which was not only punishment and intimidation, but also the correction of criminals through awareness of their guilt, repentance and systematic work. The basis of the prison regime had to be division of prisoners into classes, solitary confinement, strict discipline and spiritual care. Despite the lack of practical implementation, the Penitentiary Act was essential to further improvement of the operation of existing detention facilities and to building of new prisons throughout the country.

During the 70's of the 18th century prison transformations in the UK were only part of social reform, not an independent direction, as there were no radical changes in public policy and the penal system.

Keywords: United Kingdom; social reforms; prison; transportation; solitary confinement; hard labour; the Penitentiary Act 1779. 